OPEN ACCESS

Edited by:

Gilles Blancho,

University of Nantes, France

Reviewed by:

Carla Baan,

Erasmus University Rotterdam,

Netherlands

Eric Spierings,

Utrecht University, Netherlands

*Correspondence:

Gavin J. Pettigrew

gjp25@cam.ac.uk

Specialty section:

This article was submitted to Alloimmunity and Transplantation,

a section of the journal

Frontiers in Immunology

Received: 12 August 2018

Accepted: 17 October 2018

Published: 05 November 2018

Citation:

Siu JHY, Surendrakumar $\mathrm{V}$

Richards JA and Pettigrew GJ (2018)

$T$ cell Allorecognition Pathways in

Solid Organ Transplantation.

Front. Immunol. 9:2548.

do: $10.3389 /$ fimmu.2018.02548

\section{T cell Allorecognition Pathways in Solid Organ Transplantation}

\author{
Jacqueline H. Y. Siu, Veena Surendrakumar, James A. Richards and Gavin J. Pettigrew* \\ Department of Surgery, University of Cambridge, Cambridge, United Kingdom
}

Transplantation is unusual in that $\mathrm{T}$ cells can recognize alloantigen by at least two distinct pathways: as intact $\mathrm{MHC}$ alloantigen on the surface of donor cells via the direct pathway; and as self-restricted processed alloantigen via the indirect pathway. Direct pathway responses are viewed as strong but short-lived and hence responsible for acute rejection, whereas indirect pathway responses are typically thought to be much longer lasting and mediate the progression of chronic rejection. However, this is based on surprisingly scant experimental evidence, and the recent demonstration that $\mathrm{MHC}$ alloantigen can be re-presented intact on recipient dendritic cells - the semi-direct pathway-suggests that the conventional view may be an oversimplification. We review recent advances in our understanding of how the different $\mathrm{T}$ cell allorecognition pathways are triggered, consider how this generates effector alloantibody and cytotoxic CD8T cell alloresponses and assess how these responses contribute to early and late allograft rejection. We further discuss how this knowledge may inform development of cellular and pharmacological therapies that aim to improve transplant outcomes, with focus on the use of induced regulatory $T$ cells with indirect allospecificity and on the development of immunometabolic strategies.

\section{KEY POINTS}

- Acute allograft rejection is likely mediated by indirect and direct pathway CD4 T cell alloresponses.

- Chronic allograft rejection is largely mediated by indirect pathway CD4 T cell responses. Direct pathway recognition of cross-dressed endothelial derived MHC class II alloantigen may also contribute to chronic rejection, but the extent of this contribution is unknown.

- Late indirect pathway CD4T cell responses will be composed of heterogeneous populations of allopeptide specific $\mathrm{T}$ helper cell subsets that recognize different alloantigens and are at various stages of effector and memory differentiation.

- Knowledge of the precise indirect pathway CD4T cell responses active at late time points in a particular individual will likely inform the development of alloantigen-specific cellular therapies and will guide immunometabolic modulation.

Keywords: T cell allorecognition, transplantation, indirect presentation, cytotoxic CD8 T cells, T follicular helper cell, germinal center, exhaustion, chronic allograft vasculopathy 


\section{INTRODUCTION}

Although innate recognition of alloantigen can exhibit properties more typically associated with adaptive immunity (1-3), the conventional $\mathrm{T}$ cell response to alloantigen is still considered critical for determining short and long-term outcomes for solid organ transplants. Transplantation is unusual in that alloantigen can uniquely be recognized by at least two pathways; the indirect and the direct. The oft-repeated mantra that the short-lived direct pathway is responsible for acute rejection and the longer lasting indirect pathway mediates chronic rejection is based upon little evidence and, as highlighted by the recent description of a third semi-direct pathway, is an oversimplification. Here we review recent advances in our understanding of how different $\mathrm{T}$ cell allorecognition pathways may contribute to rejection and consider how this knowledge may inform development of cellular and pharmacological therapies that aim to improve transplant outcomes.

\section{PATHWAYS OF T CELL ALLORECOGNITION}

\section{Direct Pathway}

The direct pathway, whereby recipient CD4 and CD8 T cells recognize intact $\mathrm{MHC}$ class II and class I alloantigen, respectively on the surface of donor antigen presenting cells (APCs) (Figure 1A), was for several decades considered the dominant pathway responsible for transplant rejection. Initially proposed on the basis of the ex vivo mixed leukocyte reaction (4), understanding of the direct pathway has evolved, through a series of seminal publications (5-8), to encompass the passenger leucocyte theory-that allograft rejection is triggered by directpathway recognition of donor dendritic cells that have migrated from the allograft to host secondary lymphoid tissue.

Up to $10 \%$ of a recipient's T cells recognize a single $\mathrm{MHC}$ alloantigen; a peculiarity made all the more anomalous by the lack of an obvious evolutionary advantage (9-11). Two explanatory models have been proposed $(12,13)$ : According to the high determinant density model, every MHC molecule on the surface of a donor APC is recognized as foreign, compared to only around 150 complexes per cell on host APCs following selfrestricted processing and presentation of conventional antigen $(14,15)$. Further amplification is provided through the ability of one particular MHC alloantigen to present multiple different peptides: the multiple binary complex model. Crystallographic analysis of the interaction between an allospecific $\mathrm{T}$ cell and its target MHC alloantigen has revealed a similar orientation as occurs for conventional T cell responses, suggesting that the high precursor frequency of direct pathway $\mathrm{T}$ cell clones is principally due to multiple binary complex recognition $(16,17)$.

\section{Indirect Pathway}

The demonstration by Lechler and Batchelor that allografts that lacked passenger leucocytes could still be rejected (9, 10) suggested that alloantigen could also be recognized conventionally, as self-restricted processed peptide (Figure 1B).
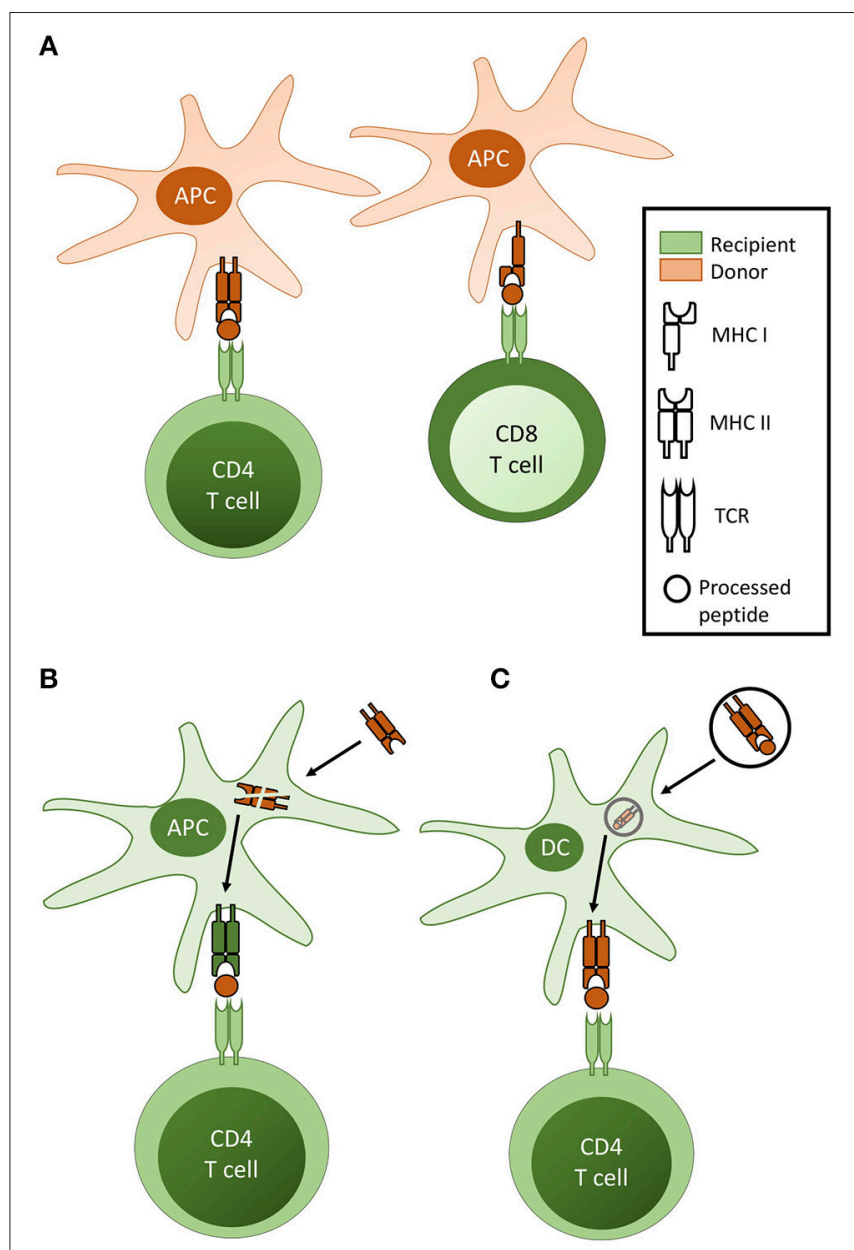

FIGURE 1 | Pathways of T cell allorecognition. (A) In direct pathway allorecognition, MHC Class II and Class I alloantigen is recognised as intact protein on the surface of donor antigen presenting cells (APC) by CD4 and CD8T cells respectively. (B) In indirect allorecognition, graft alloantigen (typically MHC antigen) is internalised by recipient APC [typically a dendritic cell $(\mathrm{DC})]$, processed and presented as peptide fragments in the context of recipient MHC, for self-restricted recognition by recipient $\mathrm{T}$ cells. Although in theory both CD4 and CD8T cells can recognise processed alloantigen via the indirect pathway, indirect pathway CD8 T cell responses are not considered relevant for the rejection of vascularized allografts. (C) In semi-direct allorecognition, MHC alloantigen is acquired by recipient DC but, rather than presentation as processed allopeptide, is re-presented as conformationally intact protein.

Termed the indirect pathway, its role in allograft rejection has been increasingly emphasized $(11,12,18,19)$.

Given the number of mismatched major and minor histocompatibility antigens contained within a transplanted organ, a potentially huge number of disparate allopeptide epitopes could be generated for recognition via the indirect pathway. Despite this, the alloimmune response is generally directed against a limited number of immunodominant epitopes (13-15, 20). Immunodominance is, however, not fixed and may shift with time, with patterns of dominance likely influenced by prior immunization history. Such epitope spreading may underpin chronic rejection (21). 


\section{Semi-direct Pathway}

The demonstration that intact antigen could be transferred between different cell types $(16,17,22)$, raised the possibility that direct pathway $\mathrm{T}$ cell recognition of intact alloantigen may occur on host dendritic cells (Figure 1C). This has been difficult to prove, but received experimental support from the demonstration of alloantigen transfer between cultured DCs (23), and following transfer of DCs from one mouse strain into the peritoneal cavity of another (24). Subsequent murine studies have confirmed the acquisition of intact alloantigen by recipient DCs following challenge with a vascularized allograft (25-29). The mechanisms by which alloantigen is transferred remain unclear, with early studies suggesting cell-to-cell contact was required $(23,30,31)$, but more recent publications showing a role for extracellular vesicles $(32,33)$.

Although discussed as a distinct pathway, semi-direct allorecognition is a means by which recipient $\mathrm{T}$ cells may recognize "intact" alloantigen. This will result in activation of the same $\mathrm{T}$ cell clones as would respond via direct pathway allorecognition. In contrast, those $\mathrm{T}$ cell clones responding to the processed alloantigen via the indirect pathway are likely to be very different.

\section{THE ROLE OF DIFFERENT ALLORECOGNITION PATHWAYS IN ALLOGRAFT REJECTION}

The contribution of different allorecognition pathways to allograft rejection will be governed by two main factors: the presence of target epitope and the ability of that pathway, once activated, to mediate graft damage. Differences in the duration of direct and indirect $\mathrm{T}$ cell alloresponses are thus likely to profoundly influence their ability to mediate early and late graft rejection.

\section{Duration of CD4 T cell Alloresponses Activation of CD4 T cell Clones With Direct Allospecificity}

Experimental and human transplant studies suggest that direct pathway CD4 $\mathrm{T}$ cell responses are limited to the first few weeks after transplantation (34-36), with murine transplant models suggesting that its duration correlates with the lifespan of the donor DC fraction $(35,37)$. A small number of human studies have similarly suggested that direct pathway CD4 T cell activation is short-lived $(21,34,38,39)$.

However, recent publications from the Morelli and Benichou groups challenge these assumptions. Their studies suggest that "direct" pathway activation is largely due to recognition of intact alloantigen acquired onto the surface of host APCs by transfer of donor-derived extracellular vesicles-in essence, semi-direct allorecognition $(32,33)$. Whether the Morelli and Benichou findings represent a radical reappraisal of direct pathway $\mathrm{T}$ cell activation is not clear. Their experimental systems were not designed to examine semi-direct presentation in isolation of the conventional donor $\mathrm{DC} /$ recipient $\mathrm{T}$ cell interaction, and it is difficult to know the relative contribution of both to $\mathrm{T}$ cell activation. Nevertheless, by theoretically dissociating activation of directly alloreactive CD4 T cells from expression of target MHC class II alloantigen on donor APCs, the Morelli and Benichou papers raise the potential for direct pathway CD4 $\mathrm{T}$ cell activation to occur at late time points after transplantation.

\section{Activation of CD4 T cell Clones With Indirect Allospecificity}

It is more straightforward to theorize how indirect pathway CD4 T cell responses against self-restricted processed alloantigen can last much longer than those against intact alloantigen. In support, several animal studies have ascribed a functional role for the indirect pathway CD4 $\mathrm{T}$ cell response in the progression of chronic allograft rejection (40-43). Late anti-allopeptide reactivity has been similarly described in human transplant patients with chronic graft dysfunction (34, 38, 44-46), though it is unclear from these studies whether the $\mathrm{T}$ cell responses identified ongoing naïve responses or recall of alloreactive $\mathrm{T}$ cell memory established early after transplant.

On the assumption that the crux to late alloreactive $\mathrm{T}$ cell activation is continued presentation of stimulatory target epitope, we have recently studied the division of monoclonal populations of naive TCR-transgenic CD4 T cells that recognize a specific allopeptide epitope and that are adoptively transferred at late time points after murine heart transplantation (35). These experiments confirmed that in the mouse, direct pathway CD4 T cell activation is dependent upon the donor hematopoietic fraction, with responses not detectable beyond the first week. In contrast, chronic rejection was associated with ongoing presentation of processed MHC class I alloantigen and late activation of the responding indirect-pathway CD4 $\mathrm{T}$ cell population.

The indirect pathway CD4 T cell response has generally been considered as a single entity but use of monoclonal $\mathrm{T}$ cell lines with precise allospecificity enabled us to show that there was considerable heterogeneity within the response. Unlike the response against $\mathrm{MHC}$ class I allopeptide, the indirect pathway response against $\mathrm{MHC}$ class II allopeptide was as short-lived as the direct pathway, and not detectable beyond the first week of transplantation, because it too was dependent upon the donor hematopoietic fraction as a source of MHC class II alloantigen (35).

\section{Duration of CD8 T cell Alloresponses}

The presentation of intact MHC class I alloantigen by migrating donor DCs, in the context of pro-inflammatory co-stimulatory ligands, is generally considered the principal mechanism for generating direct pathway CD8 T cell alloimmunity. However, other than at artificially very high precursor frequencies (47), differentiation of naïve CD8 T cells to cytotoxic effectors requires help from activated allospecific CD4 T cells. Hence, the duration of the CD8T cell alloresponse will partly be governed by availability of CD4 T cell help.

A series of seminal publications (48-50) have highlighted that for conventional immune responses, CD4 T cell help is delivered, not to the CD8 T cell, but through "licensing" of an intermediary APC, which, crucially, presents both MHC class I and class II 
restricted target epitopes for $\mathrm{CD} 8$ and $\mathrm{CD} 4 \mathrm{~T}$ cell recognition, respectively. This enables the formation of a linked "three-cell" cluster (Figure 2A). With regards to alloreactive CD8 T cell alloimmunity, a similar three-cell cluster can be created that incorporates the donor DC and a direct pathway CD4 T cell (Figure 2B). Murine studies suggest this provides CD4 T cell help for generating cytotoxic CD8 T cell responses immediately after transplant (51). Thus, if help for alloreactive CD8 T cells can only be delivered by $\mathrm{CD} 4 \mathrm{~T}$ cells with direct allospecificity, then the window for CD8 $\mathrm{T}$ cell activation is limited to the immediate post-transplant period.

Late CD8 T cell alloimmunity may, however, be generated through provision of help from $\mathrm{CD} 4 \mathrm{~T}$ cells with indirect allospecificity. In support, murine studies have convincingly shown that, immediately after transplantation, indirect pathway $\mathrm{CD} 4 \mathrm{~T}$ cells can provide CD8 $\mathrm{T}$ cell help (52). This raises further questions about how such help is delivered, because it requires the formation of a cumbersome four-cell cluster model (Figure 2C), in which help is delivered by CD4 T cells recognizing processed allopeptide presented by a recipient APC to $\mathrm{CD} 8 \mathrm{~T}$ cells responding to intact MHC class I on the surface of a donor APC. Moreover, the lack of apparent linkage between the donor APC / CD8 T cell couplet and the recipient APC / CD4 T cell couplet raise concerns of inappropriate and uncontrolled CD8 T cell activation, because similar unlinked help could theoretically be provided by bystander CD4 T cell responses to unrelated antigen. Semi-direct presentation of MHC class I alloantigen by recipient DCs potentially provides an elegant solution, if one assumes that the same DCs simultaneously present class I alloantigen both as intact protein and processed peptide. This would enable formation of a threecell cluster, in which linked help is provided by indirect pathway CD4 T cells (Figure 2D). Murine studies by ourselves and others have demonstrated simultaneous expression of intact and processed alloantigen by recipient DCs following transplantation $(26,27)$, and adoptive transfer studies have further suggested that these 'cross-dressed' DCs can prime effective CD8 T cell cytotoxic alloresponses (27).

Demonstrating the functional relevance of this pathway is challenging, because it is difficult to devise model systems in which semi-direct recognition can be studied in isolation from direct pathway responses. We have shown that recipient DCs are required for generating a cytotoxic CD8 $\mathrm{T}$ cell population that effects rejection of heart grafts that are otherwise unable to provoke conventional direct pathway $\mathrm{T}$ cell responses (29). Similarly, Smyth et al. have recently demonstrated that recipients that cannot mount indirect pathway $\mathrm{T}$ cell responses are still capable of effecting acute cellular rejection of heart grafts, but that this rejection is dependent upon the recipient DC fraction (28). While both these papers support an independent functional role for semi-direct allorecognition in graft rejection, it should be stressed that they do not necessarily show that this pathway is dominant or more effective than conventional direct pathway responses.

In summary, animal studies provide strong support that immediately after transplantation, strong CD4 $\mathrm{T}$ cell-dependent cytotoxic CD8 $\mathrm{T}$ cell responses can be generated by direct and semi-direct presentation of class I alloantigen. The extent to which these mechanisms, particularly the semidirect presentation of parenchymal MHC class I alloantigen, can drive late CD8 $\mathrm{T}$ cell activation has still to be clarified. In this respect, although clinical studies have reported late direct pathway responses in human transplant patients (5356), this is generally based upon in vitro recall IFN- $\gamma$ responses of recipient peripheral blood mononuclear cells (PBMCs). Definitive evidence, either experimental or clinical, for late alloreactive CD8 T cell cytotoxicity is lacking (57).

\section{ALLORECOGNITION PATHWAYS AND EFFECTOR MECHANISMS}

\section{Early Acute Rejection}

Given the above, one would anticipate that direct pathway responses dominate early after transplantation, with the $\mathrm{CD} 4 \mathrm{~T}$ cell response central. Full CD4 $\mathrm{T}$ cell activation requires continued TCR engagement (58), with target MHC class II alloantigen expressed on the surface of donor APCs or re-presented by recipient DCs intact. $\mathrm{CD} 4 \mathrm{~T}$ cells do not generally exhibit cytotoxic activity, and although direct pathway CD4 T cells can effect allograft rejection autonomously $(59,60)$, their greatest contribution to graft rejection is likely to be as helpers to direct pathway CD8 $\mathrm{T}$ cells (Figure 2B). Once activated, the cytotoxic CD8 $\mathrm{T}$ cell alloresponse can target all MHC class I alloantigen expressing cells of the graft.

Although indirect pathway $\mathrm{CD} 8 \mathrm{~T}$ cell recognition of processed alloantigen can occur, this only appears relevant for the rejection of skin $(61,62)$ and not vascularized allografts (63), because target epitope (recipient MHC class I antigen) is expressed in the former as a consequence of host endothelial ingrowth.

Murine transplant models have confirmed that indirect pathway CD4 $\mathrm{T}$ cell activation also occurs early after transplantation $(14,64,65)$. Although adoptive transfer studies have suggested that indirect pathway $\mathrm{CD} 4 \mathrm{~T}$ cells may have an autonomous effector role in acute rejection $(42,66,67)$, this possibly occurs only with artificially high numbers of transferred cells. As with indirect pathway CD8 T cell responses, the target allopeptide epitope for indirect pathway $\mathrm{CD} 4 \mathrm{~T}$ cells is unlikely to be expressed at early time points within the transplant. Instead, indirect pathway $\mathrm{CD} 4 \mathrm{~T}$ cells are uniquely capable of providing help to alloreactive B cells for generating Ig-class switched alloantibody responses $(68,69)$; acute alloantibody-mediated rejection is thus robust clinical evidence of early indirect pathway CD4 $\mathrm{T}$ cell activation.

\section{Late Rejection}

Although semi-direct presentation of endothelial MHC class II alloantigen raises the possibility of late activation of $\mathrm{CD} 4 \mathrm{~T}$ cell clones with direct allospecificity, this remains unproven. Chronic rejection is more plausibly mediated by indirect pathway $\mathrm{CD} 4 \mathrm{~T}$ cell responses directed against major and minor mismatched histocompatibility alloantigens $(34,38,44-$ 46). The principal role for indirect pathway $\mathrm{CD} 4 \mathrm{~T}$ cells in graft 


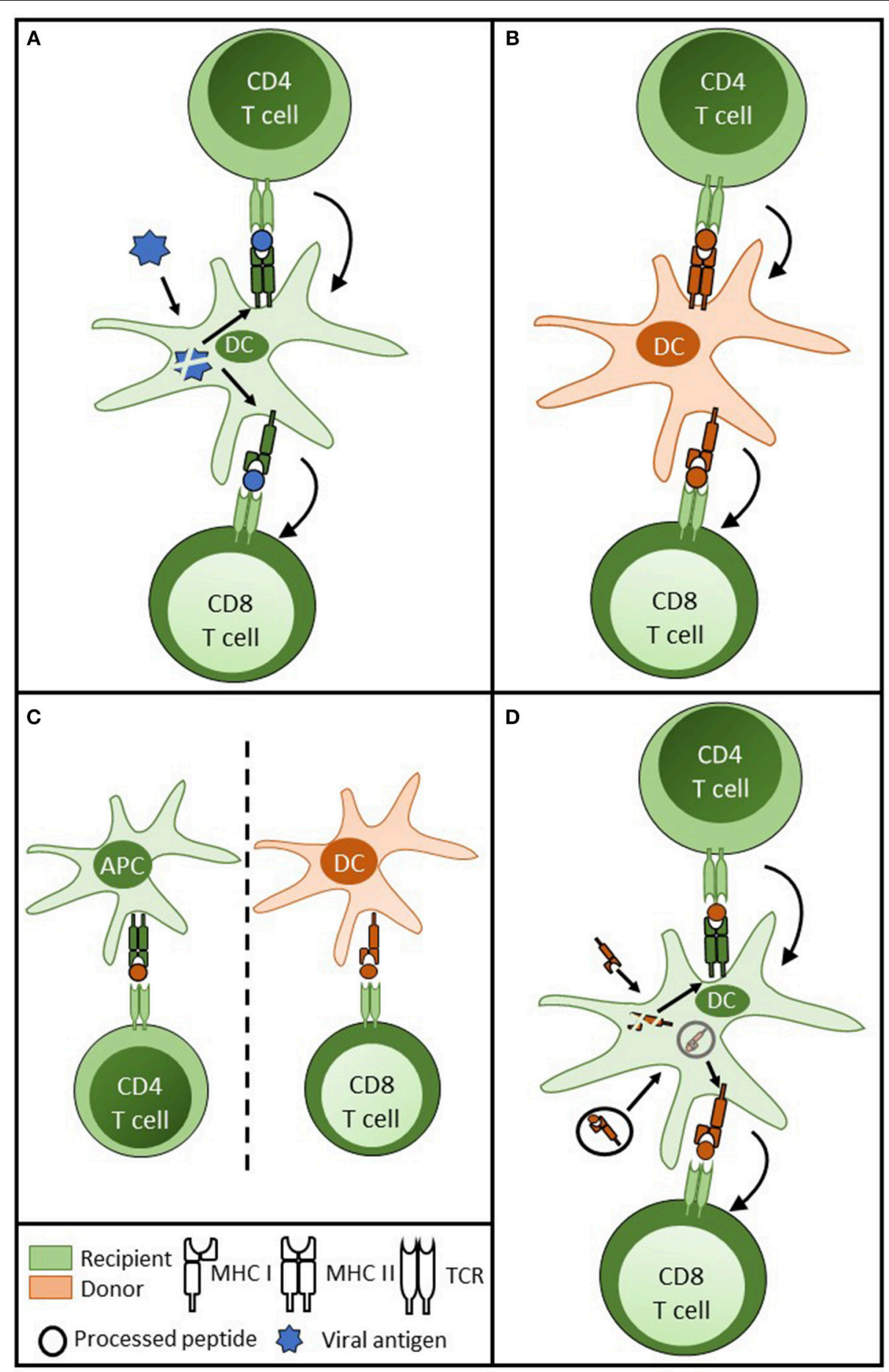

FIGURE 2 | Delivery of CD4 T cell help for cytotoxic CD8T cell alloimmunity. (A) For CD8 T cell responses against conventional protein antigen (such as viral antigen) following internalisation by the dendritic cell (DC), processed viral peptide is presented in the context of MHC class II and class I for CD4 and CD8T cell recognition, respectively. CD4 T cell help is delivered to the DC, resulting in upregulation of co-stimulatory signals on the DC surface. This in turn results in enhanced presentation and more effective priming of the CD8 T cell response. (B) In transplantation, a similar three cell cluster model is achieved by donor DC presentation of intact MHC class II and class I to direct pathway CD4 and CD8T cells. (C) Although animal models have shown that indirect pathway CD4T cells can provide effective help for cytotoxic CD8 T cell alloresponses against intact MHC class I alloantigen, this theoretically involves a cumbersome four cell cluster with two unpaired couplets: recipient APC presenting to recipient indirect pathway CD4 T cell and donor DC presenting MHC class I alloantigen to direct pathway CD8 T cells; raising concerns regarding uncontrolled CD8T cell alloresponses from bystander CD4 T cell activation. (D) These concerns are obviated if a recipient DC is able to re-present intact $\mathrm{MHC}$ class I alloantigen and processed MHC class I allopeptide simultaneously, enabling the provision of linked help from indirect pathway CD4 T cells to direct pathway CD8T cells. 
rejection is likely in providing help for humoral and cytotoxic CD8 T cell alloimmunity.

As discussed above, other than development of delayed (>6 months after transplant) acute cellular rejection in human transplant recipients, definitive evidence for late allospecific cytotoxic CD8 T cell activation is lacking. One group has identified a population of circulating "terminally differentiated" effector memory (TEMRA) CD8 T cells at late time points in a cohort of kidney transplant recipients and reported a correlation with subsequent graft dysfunction $(57,70)$. The antigen specificity of this TEMRA population was not determined, and although it did provoke endothelial activation upon in vitro culture, chronic CD8 T cell stimulation in response to continued exposure to target class I alloantigen would be expected to lead to a state of exhaustion, characterized by loss of effector status $(71,72)$. If so, it is not immediately apparent how such exhausted cells contribute to the progression of allograft vasculopathy. Exhaustion is, however, malleable, and one possibility is that late cytotoxic CD8 T cell alloresponses are rescued from exhaustion by provision of help (73), most likely from indirect pathway CD4 T cells and formation of a three-cell cluster involving the recipient DC (Figure 2D).

In contrast, de novo generation of class-switched donor specific alloantibody (DSA), sometimes years after transplantation, robustly demonstrates that the indirect pathway helper CD4 T cell / allospecific B cell axis is operational at late time points after transplantation. Late-developing DSA responses are generally long-lived, suggesting deposition of allospecific long-lived plasma cells (LLPCs) in the bone marrow. These are thought to be an exclusive product of a germinal center (GC) response, and in this regard, a consistent feature in our recent murine studies on chronic heart allograft rejection is the presence of splenic GC activity at late time points after transplantation $(35,74)$. Long-lasting GC responses [as typically found in the gut and in humoral autoimmune disease $(75,76)]$ are maintained by delivery of help from specialized $\mathrm{T}$ follicular helper $\left(\mathrm{T}_{\mathrm{FH}}\right)$ cells (77), and thus their presence in our transplant models suggests ongoing $\mathrm{T}_{\mathrm{FH}}$ cell differentiation from indirect pathway responses against persistently presented target allopeptide epitope. By using synthetic MHC class II / allopeptide tetramers to map the endogenous indirect pathway CD4 T cell population, we confirmed that this late presentation of allopeptide epitope was associated with ongoing division and marked late expansion ( $\sim 10,000$ fold $)$ of the responding $\mathrm{T}$ cell population (35).

Interestingly, this expanded population also exhibited features consistent with exhaustion. Exhaustion is a state distinct from and senescence, and is characterized by progressive loss of effector function and expression of multiple inhibitory receptors (72). It has garnered much attention recently, because it is perhaps not the propensity to trigger self-reactive responses, but the ability, or otherwise, to counter their progression through development of an exhaustive state that may ultimately determine outcomes for autoimmune disease $(71,78)$. Our studies highlight that exhaustion is likely to impact on graft outcome, but in doing so, raises an important question: if, as seems probable, ongoing indirect pathway $\mathrm{CD} 4 \mathrm{~T}$ cell responses against persistent allopeptide epitope are a critical factor in the progression of chronic rejection, how is this achieved despite the development of an exhausted state? This question has not been addressed experimentally, because exhaustion is only now beginning to be considered in relation to transplantation (79), but we speculate several solutions:

\section{Exhausted Allospecific CD4T cells Retain Effector Function}

Exhausted T cells have been shown in some models to provide important viral control (80), which raises the possibility that exhausted indirect pathway CD4T cells may still mediate allograft progression. Fahey et al. recently reported that in a murine model of chronic lymphocytic choriomeningitis virus infection, exhausted CD4T cells acquire phenotypic characteristics, such as $\mathrm{C}-\mathrm{X}-\mathrm{C}$ motif chemokine receptor 5 (CXCR5), inducible $\mathrm{T}$ cell co-stimulator (ICOS), OX40, and $\mathrm{PD}-1$, that resemble the $\mathrm{T}_{\mathrm{FH}}$ subset (81). Moreover these skewed, exhausted cells expressed interleukin-21 (IL-21), a key cytokine for $\mathrm{T}_{\mathrm{FH}}$ cell function (82), and could provide help for late antiviral antibody responses. Thus, these experiments may explain the simultaneous findings of exhaustion and persistent germinal center humoral immunity in our transplant model (35). Interestingly, IL-21 secretion by the helper CD4 T cell subset is also critical in preventing the development of CD8 $\mathrm{T}$ cell exhaustion and providing control in chronic viral infection (83-85), raising the possibility that in a transplanted individual, exhausted $\mathrm{T}_{\mathrm{FH}}$-like $\mathrm{CD} 4 \mathrm{~T}$ cells also promote the development of late cytotoxic CD8 T cell alloresponses. Not all chronic disease models, however, support a functional role for exhausted CD4 $\mathrm{T}$ cells in promoting late humoral immunity (86), and thus the relevance of the exhausted $\mathrm{T}_{\mathrm{FH}}$ cell subset to chronic allograft vasculopathy still requires clarification. One recent study has, for example, suggested that the development of exhaustion is associated with prolonged allograft survival (87).

\section{Exhaustion Is Bypassed by Epitope Diversification}

One mechanism by which chronic autoimmune responses are sustained despite the propensity for exhaustion is through intraand inter-molecular epitope diversification or "spreading" (13). As responses against a dominant epitope become exhausted, this enables the focus to shift to encompass new target $\mathrm{T}$ cell epitopes within the same, or completely different molecules. Diversification to sub-dominant (88), as well as cryptic self-epitopes $(14,89,90)$ has been described in experimental transplant models, and a seminal publication by the Suciu-Foca group has reported an association with the development of chronic allograft vasculopathy in human heart transplant recipients (21). Epitope spreading, even to target a second alloantigen on the graft, may permit humoral responses against the first alloantigen to be maintained, because of the ability of the allospecific $B$ cell to acquire additional graft alloantigen as it internalizes target alloantigen (91). 


\section{Recall of Memory CD4T cell Responses}

In contrast to murine transplant models, which generally study naïve $\mathrm{T}$ cell responses to alloantigen, recall memory responses, often from cross-reactive heterologous immunity, are considered a sizeable component of the alloresponse encountered in clinical practice (92-94), and are particularly relevant because of their relative insensitivity to immunosuppressive agents. Of note, unlike central memory alloreactive CD4T cells (generated following acute allograft rejection), exhausted alloreactive $\mathrm{CD} 4 \mathrm{~T}$ cells (purified from recipients undergoing chronic rejection) were unable to provide co-stimulation-independent help for the production of alloantibody in our experimental system (35). This raises the possibility that in clinical practice, $\mathrm{T}$ cell help for generating late humoral alloimmunity is provided by recall responses of allospecific memory CD4 T cells that have been deposited early after transplantation, rather than by a chronically activated, but exhausted, population. Certainly, it is unlikely that exhausted CD4 T cells will respond to target epitope in the typical ELISpot assays used clinically to evaluate late direct and indirect pathway activation (53-56); these assays are instead generally considered a marker of memory recall, particularly those that involve prolonged in vitro culture (21). This may explain why in clinical transplantation late de novo donor specific alloantibody responses appear to focus on disparate MHC class II, rather than MHC class I, alloantigens (95, 96). Although MHC class II alloantigen is likely to be upregulated on the endothelium of human allografts, MHC class I alloantigen will still be expressed more widely and much more abundantly within the graft, and certainly there is no a priori reason why disparate MHC class I alloantigens will be less immunogenic than disparate class II alloantigens. Thus, MHC class I alloantigen may be presented as processed allopeptide continually, resulting in chronic activation and exhaustion within the responding helper CD4 T cell population, whereas levels of MHC class II alloantigen expression within the graft may fluctuate and fall below a threshold at which the CD4T cell response terminates and effective anamnestic responses are generated. Subsequent upregulation of class II alloantigen expression on the graft endothelium in response to stress from, for example, concurrent viral infection, may result in provision of help for generating late anti-class II alloantibody through recall responses of deposited memory class II allopeptide-specific CD4 T cells. Although speculative, this would be consistent with the reported association between the development of class II allopeptidespecific CD4 T cell memory responses (as determined by in vitro ELISpot culture assay) and chronic rejection in human heart transplant recipients (21).

\section{TARGETING LATE T CELL ALLORESPONSES TO PREVENT PROGRESSION OF CHRONIC REJECTION}

A better understanding of the allorecognition pathways active at late time points after transplantation will inform the development of tolerogenic strategies that aim to prevent progression of allograft vasculopathy and prolong allograft survival. Two approaches will be considered further: regulatory $\mathrm{T}$ cell therapy and targeting the metabolic pathways that sustain chronic $\mathrm{T}$ cell alloresponses.

\section{Regulatory T cells}

Numerous cells with immunoregulatory potential are described (97). Here we focus on the classical CD25 ${ }^{\text {pos }}$ CD4 $\mathrm{T}$ regulatory cell (T-reg) $(98,99)$. Naturally-occurring, thymus derived T-regs (nT-regs) are defined by the master transcription factor forkhead box P3 (FOXP3) (100, 101) and provide essential control of autoimmunity through: absorption of pro-inflammatory IL-2; CTLA-4-mediated masking of CD80 and CD86 co-stimulatory ligands on APCs; expression of immune-inhibitory molecules (IL-10, IL-35, TGF- $\beta$ ); and granzyme-mediated killing of APCs (102).

FOXP3-expressing T-regs develop in the periphery (pTreg) upon engagement with target epitope in a TGF- $\beta$ rich environment $(103,104)$. While nT-regs are polyclonal, pTregs are defined by antigen exposure. This has important consequences for T-reg therapy, because although T-regs may exhibit non-antigen-specific suppressor function, more potent inhibition occurs upon engagement of the TCR. In support, preclinical studies suggest that alloantigen-specific induced T-regs (iT-reg) are more effective than nT-regs in preventing allograft rejection (105-107).

Current translational transplant studies are focused upon the delivery of T-regs with direct allospecificity $(97,99,108-$ 112), partly because these can be generated more readily than indirect pathway T-regs. These are likely to be most effective in preventing early acute rejection, albeit the strong proinflammatory environment immediately after transplantation may favor deleterious trans-differentiation of the administered T-regs to $\mathrm{T}$ effector status (113). Control of acute rejection is not a major clinical problem, and while early administration of direct pathway T-regs may have long-lasting consequences (114), based on the above consideration of expression of target epitope at late time points, one would predict that chronic rejection will be better controlled by iT-regs with indirect allospecificity. This is supported by murine studies $(106,107,115,116)$. If so, the challenge will be in determining not only which mismatched major and minor histocompatibility alloantigens are being actively processed, but also the precise self-restricted allopeptide epitopes that are generated by this processing. This may not be as daunting as first appears, because as long as target epitope is expressed, transfer of allopeptide-specific T-regs may dominantly inhibit concurrent indirect pathway responses against other alloantigens (117). Subsequent epitope diversification that shifts the focus of the indirect pathway CD4 T cell response to new epitopes on different alloantigens should be similarly controlled by "infectious" tolerogenic mechanisms $(118,119)$.

\section{T cell Metabolic Pathways}

It is likely that the alloreactive CD4 $\mathrm{T}$ cell response at late time points after transplantation will comprise a number of different populations with specificities for different alloantigens. These populations will further differ in their helper $\mathrm{T}$ cell subset polarization $\left(\mathrm{T}_{\mathrm{H}} 1, \mathrm{~T}_{\mathrm{H}} 2, \mathrm{~T}_{\mathrm{H}} 17, \mathrm{~T}_{\mathrm{FH}}\right)$, and in their stage 
of effector to memory transition. This will include populations of allospecific CD4 T cells that have acquired an exhausted phenotype or have undergone peripheral differentiation into regulatory $\mathrm{T}$ cells (pT-reg). As discussed above, the relative contribution of these different populations to the progression of allograft vasculopathy has still to be clarified, but it is now apparent that the individual stages of $\mathrm{T}$ cell differentiation are underpinned by profoundly different metabolic states, and it is the metabolic environment that dictates $\mathrm{T}$ cell differentiation (120-122). Immunometabolism is still an emerging field but raises the potential that specific metabolic pathways could be targeted with the expectation of improvements in transplant outcomes.

Naïve $\mathrm{T}$ cells persist in a catabolic state, with their bioenergetic requirements met largely by mitochondrial oxidative phosphorylation (OXPHOS). Upon binding target antigen, activated $\mathrm{T}$ cells switch their metabolic profile to aerobic glycolysis, characterized by marked augmentation in glycolysis and a lesser, but nevertheless critical (123), increase in OXPHOS (Figure 3). Central to these changes are signaling via the phosphoinositide 3-kinase (PI3K)-AKT1-mammalian target of rapamycin (mTOR) axis (124-126) and upregulation of the transcription factors MYC and hypoxia-inducible factor $1 \alpha(\mathrm{HIF} 1 \alpha)$. This results in increased amino acid and glutamine transfer to fuel glutaminolysis and glycolysis. Although the switch to glycolysis is clearly, when oxygen is otherwise abundant, an inefficient means of producing ATP; it does generate the metabolic intermediates for synthesizing the nucleotides and amino acids required for differentiation and division. It also produces acetyl-CoA for manufacturing lipids (127). Upon pathogen clearance, the activated T cell population undergoes contraction by apoptosis, leaving a small population of long-lived memory $\mathrm{T}$ cells. These cells revert to a catabolic state, but unlike naïve cells, OXPHOS is maintained, at least in part, by mitochondrial fatty acid oxidation (FAO), in which IL-7 and IL-15 signaling mediates AMP-activated protein kinase (AMPK)-dependent increases in mitochondrial biomass and spare respiratory capacity (128-131).

Not all effector T cell populations rely upon aerobic glycolysis, and most notably, pT-regs rely upon OXPHOS and FAO metabolism $(132,133)$. Consequently, inhibition of glycolysis, either by blocking mTOR1c or downstream HIF1 $\alpha$ signaling, promotes a switch from $\mathrm{T}_{\mathrm{H}} 17$ to $\mathrm{pT}$-reg differentiation (134136). The $\mathrm{T}_{\mathrm{FH}}$ subset is similarly more dependent upon OXPHOS than the classical $\mathrm{T}_{\mathrm{H}} 1$ subset (137), and Bcl-6 expression (the key transcription factor for this subset) represses glycolysis (138). This possibly counters the high glucose requirements associated with the germinal center $\mathrm{B}$ cell response. Finally, although exhausted T cells exhibit typical aerobic glycolysis at initiation of the response, continued antigen binding to the TCR results in downregulation of the PI3K-AKT1-mTOR signaling pathway (139) and NFATC-mediated expression of PD-1 and other inhibitory ligands $(140,141)$. This results in inhibition of glycolysis and increased FAO (142).

From the discussions presented so far, we make two predictions: firstly, that at late time points graft alloantigen will be continually processed by recipient APCs for recognition by CD4 T cells with indirect allospecificity; and secondly, that the metabolic profile governing these late chronic responses will be skewed from glycolysis and instead focus on OXPHOS, perhaps with a reliance on FAO. If so, then transplant outcomes will be determined by the relative contributions of the indirect pathway $\mathrm{T}$ cell subsets that meet those energy requirements, with memory or $\mathrm{T}$ follicular helper cell responses being potentially destructive, while exhausted or regulatory $\mathrm{T}$ cell responses being neutral or beneficial. Therapeutic targeting of immunometabolic pathways is a developing field, and approaches so far in autoimmunity (143) and transplantation (144) have generally focused on inhibiting glycolysis and preventing the differentiation of $\mathrm{T}$ effector cells. Such an approach may not be particularly effective if commenced at late time points after transplantation when glycolysis is not the dominant metabolic pathway. In this regard, Byersdorfer et al. have recently shown that the administration of etomoxir, an agent that blocks FAO by irreversibly inhibiting carnitine palmitoyl-transferase 1 (CPT1), improved late disease scores in a murine model of chronic graft-vs.-host disease (145). Interestingly, etomoxir only affected donor alloreactive $\mathrm{T}$ cells that had divided more than six times and was ineffective at preventing acute $\mathrm{T}$ effector differentiation, suggesting that similar inhibition of FAO may prevent progression of allograft vasculopathy in recipients of solid organ transplants. One potential problem with this approach is that the metabolic pathways active in the different subsets of exhausted, memory, pT-reg, and $\mathrm{T}_{\mathrm{FH}}$ cells may be quite similar. For example, while treatment with the mTOR inhibitor rapamycin would, by blocking glycolysis, be expected to promote the development of pT-regs and favor allograft survival $(134,136,146)$, it has also been shown to increase deposition of memory $\mathrm{T}$ cells (130, 147); a population that, as discussed above, may have a contrary impact on graft outcomes. The same considerations hold for other agents, such as 2-deoxyglucose, that potentially increase $\mathrm{pT}$-reg generation by blocking glycolysis (144, 148).

As the field of immunometabolism advances, it is likely that more nuanced differences in the metabolic profiles of memory, regulatory and follicular helper CD4 T cells will become apparent, and that these differences could ultimately be targeted pharmacologically. For example, the phosphatase PTEN, which is the main negative regulator of $\mathrm{PI} 3 \mathrm{~K}$, has been recently shown to be critical for maintaining T-reg stability $(149,150)$. Its conditional deletion led to increased glycolysis and redifferentiation of the T-reg population into other $\mathrm{T}$ helper cell subsets, most notably the $\mathrm{T}_{\mathrm{FH}}$ cell subset, and was associated with development of germinal center humoral autoimmunity (150).

\section{SUMMARY}

Although the CD4 T cell alloresponse is a key determinant of transplant outcomes, many aspects of this response remain unclear more than 60 years after the first human kidney transplant. It seems likely that the late CD4 T cell response will be focused on self-restricted, processed alloantigen. This response will be fluid and shift to target different epitopes on the same or different alloantigens and involve different $T$ helper cell subsets at varying stages of effector and memory differentiation. Although 


\section{A Effector T cells OXPHOS and aerobic glycolysis}

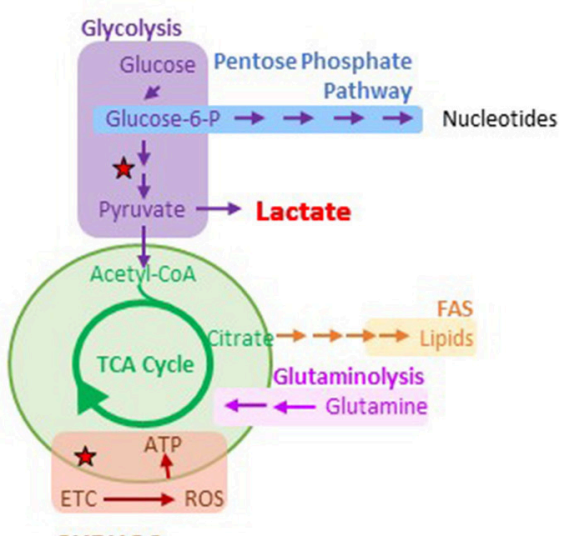

OXPHOS

\section{Memory T cells}

OXPHOS and no aerobic glycolysis

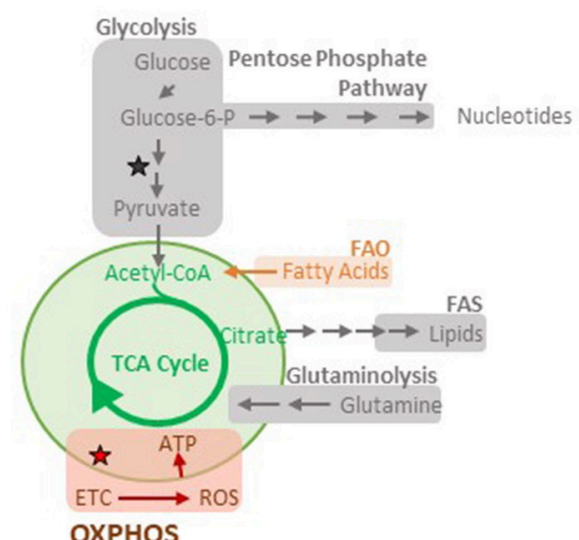

OXPHOS

\section{B Key pathways during late chronic responses}

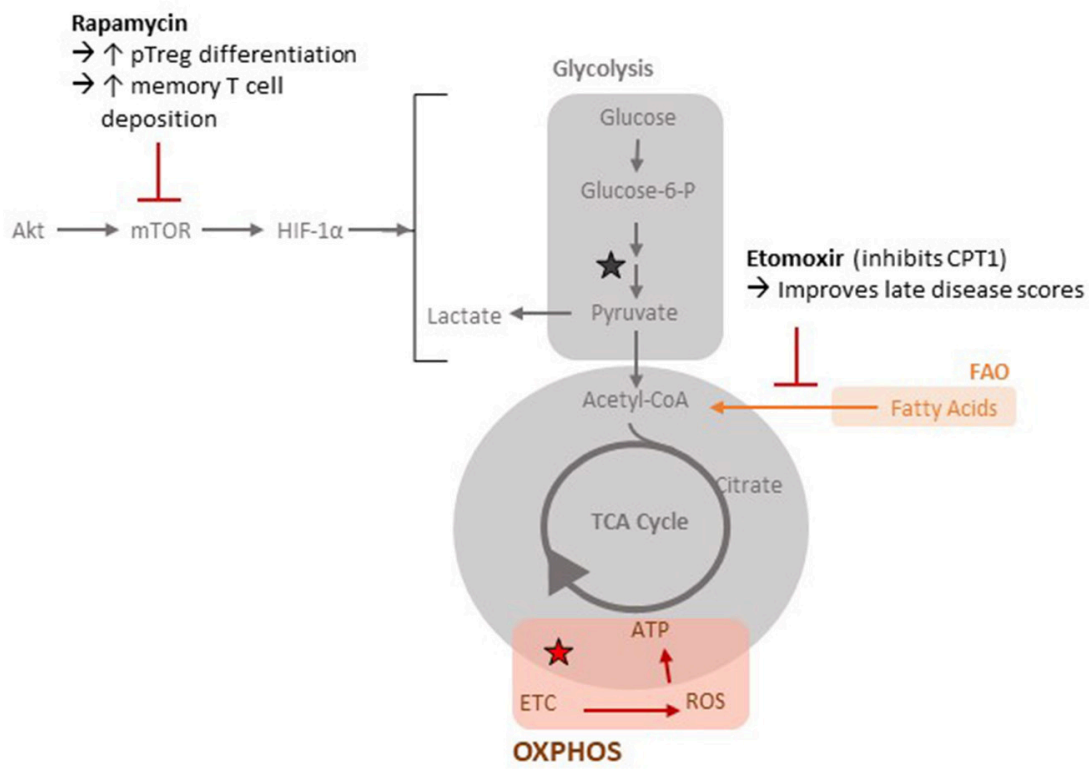

FIGURE 3 | Metabolic pathways of T cells. (A) Important metabolic pathways in T cells include glycolysis, the tricarboxylic acid (TCA) cycle (green), fatty acid oxidation (FAO), fatty acid synthesis (FAS), oxidative phosphorylation (OXPHOS) and glutaminolysis. The stars indicate reactions that generate reducing equivalents (i.e. NADH) to drive OXPHOS. Utilization of different metabolic pathways by different cell types is indicated. Greyed out pathways represent pathways that have not been defined. (B) Key metabolic pathways and inhibitors during late chronic responses are highlighted pathways by different cell types is indicated.

the future introduction of new broad acting immunosuppressive agents is likely to improve transplant outcomes, their impact may only be modest (151). Instead, alloantigen-specific cellular therapies, such as the administration of cultured T-regs, are on the cusp of entering clinical practice, and potentially offer a personalized approach to specifically inhibit deleterious alloimmune responses that are active in a particular recipient, while preserving global immune responsiveness. Key to the success of these cellular therapies will be the ability to interrogate accurately the entire CD4 T cell alloresponse in the individual, and to map currently active effector or exhausted CD4 T cell responses, as well as the recent deposition of central and effector memory $\mathrm{T}$ cells. This will require the development of experimental approaches that analyze the allospecific $\mathrm{T}$ cell 
population in situ, without the need for protracted in vitro culture and stimulation.

\section{AUTHOR CONTRIBUTIONS}

All authors contributed equally to the design and preparation of this review. JS and GP conceptualized and designed the figures.

\section{REFERENCES}

1. Lakkis FG, Li XC. Innate allorecognition by monocytic cells and its role in graft rejection. Am J Transplant. (2017) 18:289-92. doi: 10.1111/ ajt.14436

2. Oberbarnscheidt MH, Zeng Q, Li Q, Dai H, Williams AL, Shlomchik WD, et al. Non-self recognition by monocytes initiates allograft rejection. J Clin Invest. (2014) 124:3579-89. doi: 10.1172/JCI74370

3. Zecher D, van Rooijen N, Rothstein DM, Shlomchik WD, Lakkis FG. An innate response to allogeneic nonself mediated by monocytes. J Immunol. (2009) 183:7810-6. doi: 10.4049/jimmunol.0902194

4. Bain B, Vas MR, Lowenstein L. The development of large immature mononuclear cells in mixed leukocyte cultures. Blood (1964) 23:108-16.

5. Elkins WL, Guttmann RD. Pathogenesis of a local graft versus host reaction: immunogenicity of circulating host leukocytes. Science (1968) 159:1250-1.

6. Talmage DW, Dart G, Radovich J, Lafferty KJ. Activation of transplant immunity: effect of donor leukocytes on thyroid allograft rejection. Science (1976) 191:385-8. doi: 10.1126/science.1082167

7. Larsen CP, Morris PJ, Austyn JM. Migration of dendritic leukocytes from cardiac allografts into host spleens. A novel pathway for initiation of rejection. J Exp Med. (1990) 171:307-14.

8. Lakkis FG, Arakelov A, Konieczny BT, Inoue Y. Immunologic 'ignorance' of vascularized organ transplants in the absence of secondary lymphoid tissue. Nat Med. (2000) 6:686-8. doi: 10.1038/76267

9. Lechler RI, Batchelor JR. Immunogenicity of retransplanted rat kidney allografts. Effect of inducing chimerism in the first recipient and quantitative studies on immunosuppression of the second recipient. J Exp Med. (1982) 156:1835-41.

10. Lechler RI, Batchelor JR. Restoration of immunogenicity to passenger celldepleted kidney allografts by the addition of donor strain dendritic cells. $J$ Exp Med. (1982) 155:31-41.

11. Gallon L, Watschinger B, Murphy B, Akalin E, Sayegh MH, Carpenter CB. The indirect pathway of allorecognition. The occurrence of selfrestricted $\mathrm{T}$ cell recognition of allo-MHC peptides early in acute renal allograft rejection and its inhibition by conventional immunosuppression. Transplantation (1995) 59:612-6. doi: 10.1097/00007890-19950227000029

12. Harris PE, Cortesini R, Suciu-Foca N. Indirect allorecognition in solid organ transplantation. Rev Immunogenet. (1999) 1:297-308.

13. Sercarz EE, Lehmann PV, Ametani A, Benichou G, Miller A, Moudgil K. Dominance and crypticity of T cell antigenic determinants. Annu Rev Immunol. (1993) 11:729-66. doi: 10.1146/annurev.iy.11.040193.003501

14. Lovegrove E, Pettigrew GJ, Bolton EM, Bradley JA. Epitope mapping of the indirect $\mathrm{T}$ cell response to allogeneic class $\mathrm{I}$ mhc: sequences shared by donor and recipient MHC may prime $\mathrm{T}$ cells that provide help for alloantibody production. J Immunol. (2001) 167:4338-44. doi: 10.4049/jimmunol.167.8.4338

15. Benichou G, Fedoseyeva E, Lehmann PV, Olson CA, Geysen HM, McMillan $\mathrm{M}$, et al. Limited T cell response to donor MHC peptides during allograft rejection. Implications for selective immune therapy in transplantation. $J$ Immunol. (1994) 153:938-45.

16. Joly E, Hudrisier D. What is trogocytosis and what is its purpose? Nat Immunol. (2003) 4:815. doi: 10.1038/ni0903-815

\section{FUNDING}

This work was supported by the British Heart Foundation. JS is supported by the Gates Cambridge Trust, VS is supported by the Mason Medical Research Trust and JR is supported by the Evelyn Trust and the National Institute of Health Research Cambridge Biomedical Research Centre.

17. Knight SC, Iqball S, Roberts MS, Macatonia S, Bedford PA. Transfer of antigen between dendritic cells in the stimulation of primary $\mathrm{T}$ cell proliferation. Eur J Immunol. (1998) 28:1636-44.

18. Gould DS, Auchincloss H Jr. Direct and indirect recognition: the role of MHC antigens in graft rejection. Immunol Today (1999) 20:77-82.

19. Ali JM, Bolton EM, Bradley JA, Pettigrew GJ. Allorecognition pathways in transplant rejection and tolerance. Transplantation (2013) 96:681-8. doi: 10.1097/TP.0b013e31829853ce

20. Liu Z, Sun YK, Xi YP, Hong B, Harris PE, Reed EF, et al. Limited usage of T cell receptor $V$ beta genes by allopeptide-specific T cells. J Immunol. (1993) 150(8 Pt 1):3180-6.

21. Ciubotariu R, Liu Z, Colovai AI, Ho E, Itescu S, Ravalli S, et al. Persistent allopeptide reactivity and epitope spreading in chronic rejection of organ allografts. J Clin Invest. (1998) 101:398-405. doi: 10.1172/JCI1117

22. Wykes M, Pombo A, Jenkins C, MacPherson GG. Dendritic cells interact directly with naive $\mathrm{B}$ lymphocytes to transfer antigen and initiate class switching in a primary T-dependent response. J Immunol. (1998) 161:1313-9.

23. Russo V, Zhou D, Sartirana C, Rovere P, Villa A, Rossini S, et al. Acquisition of intact allogeneic human leukocyte antigen molecules by human dendritic cells. Blood (2000) 95:3473-7.

24. Herrera OB, Golshayan D, Tibbott R, Salcido Ochoa F, James MJ, MarelliBerg FM, et al. A novel pathway of alloantigen presentation by dendritic cells. J Immunol. (2004) 173:4828-37. doi: 10.4049/jimmunol.173.8.4828

25. Brown K, Sacks SH, Wong W. Extensive and bidirectional transfer of major histocompatibility complex class II molecules between donor and recipienT cells in vivo following solid organ transplantation. Faseb J. (2008) 22:3776-84. doi: 10.1096/fj.08-107441

26. Brown K, Sacks SH, Wong W. Coexpression of donor peptide/recipient MHC complex and intact donor MHC: evidence for a link between the direct and indirect pathways. Am J Transplant. (2011) 11:826-31. doi: $10.1111 / j .1600-6143.2011 .03437 . x$

27. Sivaganesh S, Harper SJ, Conlon TM, Callaghan CJ, Saeb-Parsy K, Negus MC, et al. Copresentation of intact and processed MHC alloantigen by recipient dendritic cells enables delivery of linked help to alloreactive CD8 T cells by indirect-pathway CD4 T cells. J Immunol. (2013) 190:582938. doi: 10.4049/jimmunol.1300458

28. Smyth LA, Lechler RI, Lombardi G. Continuous acquisition of MHC:peptide complexes by recipienT cells contributes to the generation of antiGraft CD8(+) T cell immunity. Am J Transplant. (2017) 17:60-8. doi: $10.1111 /$ ajt.13996

29. Harper SJ, Ali JM, Wlodek E, Negus MC, Harper IG, Chhabra M, et al. CD8 T-cell recognition of acquired alloantigen promotes acute allograft rejection. Proc Natl Acad Sci USA. (2015) 112:12788-93. doi: 10.1073/pnas.1513533112

30. Game DS, Rogers NJ, Lechler RI. Acquisition of HLA-DR and costimulatory molecules by $\mathrm{T}$ cells from allogeneic antigen presenting cells. Am J Transplant. (2005) 5:1614-25. doi: 10.1111/j.1600-6143.2005.00916.x

31. Harshyne LA, Watkins SC, Gambotto A, Barratt-Boyes SM. Dendritic cells acquire antigens from live cells for cross-presentation to CTL. J Immunol. (2001) 166:3717-23. doi: 10.4049/jimmunol.166.6.3717

32. Liu Q, Rojas-Canales DM, Divito SJ, Shufesky WJ, Stolz DB, Erdos G, et al. Donor dendritic cell-derived exosomes promote allograft-targeting immune response. J Clin Invest. (2016) 126:2805-20. doi: 10.1172/JCI84577

33. Marino J, Babiker-Mohamed MH, Crosby-Bertorini P, Paster JT, LeGuern C, Germana S, et al. Donor exosomes rather than passenger leukocytes 
initiate alloreactive $\mathrm{T}$ cell responses after transplantation. Sci Immunol. (2016) 1:8759. doi: 10.1126/sciimmunol.aaf8759

34. Baker RJ, Hernandez-Fuentes MP, Brookes PA, Chaudhry AN, Cook HT, Lechler RI. Loss of direct and maintenance of indirect alloresponses in renal allograft recipients: implications for the pathogenesis of chronic allograft nephropathy. J Immunol. (2001) 167:7199-206. doi: 10.4049/jimmunol.167.12.7199

35. Ali JM, Negus MC, Conlon TM, Harper IG, Qureshi MS, Motallebzadeh R, et al. Diversity of the CD4 T cell alloresponse: the short and the long of it. Cell Rep. (2016) 14:1232-45. doi: 10.1016/j.celrep.2015.12.099

36. Haynes LD, Jankowska-Gan E, Sheka A, Keller MR, HernandezFuentes MP, Lechler RI, et al. Donor-specific indirect pathway analysis reveals a B-cell-independent signature which reflects outcomes in kidney transplant recipients. Am J Transplant. (2012) 12:640-8. doi: 10.1111/j.1600-6143.2011.03869.x

37. Kreisel D, Krasinskas AM, Krupnick AS, Gelman AE, Balsara KR, Popma SH, et al. Vascular endothelium does not activate CD4+ direct allorecognition in graft rejection. J Immunol. (2004) 173:3027-34. doi: 10.4049/jimmunol.173.5.3027

38. Hornick PI, Mason PD, Baker RJ, Hernandez-Fuentes M, Frasca $\mathrm{L}$, Lombardi $\mathrm{G}$, et al. Significant frequencies of $\mathrm{T}$ cells with indirect anti-donor specificity in heart graft recipients with chronic rejection. Circulation (2000) 101:2405-10. doi: 10.1161/01.CIR.101. 20.2405

39. Stanford RE, Ahmed S, Hodson M, Banner NR, Rose ML. A role for indirect allorecognition in lung transplant recipients with obliterative bronchiolitis. Am J Transplant. (2003) 3:736-42. doi: 10.1034/j.1600-6143.2003.00142.x

40. Richards DM, Dalheimer SL, Ehst BD, Vanasek TL, Jenkins MK, Hertz MI, et al. Indirect minor histocompatibility antigen presentation by allograft recipienT cells in the draining lymph node leads to the activation and clonal expansion of CD4+ T cells that cause obliterative airways disease. J Immunol. (2004) 172:3469-79. doi: 10.4049/jimmunol.172.6.3469

41. Lee RS, Yamada K, Houser SL, Womer KL, Maloney ME, Rose HS, et al. Indirect recognition of allopeptides promotes the development of cardiac allograft vasculopathy. Proc Natl Acad Sci USA. (2001) 98:3276-81. doi: 10.1073/pnas.051584498

42. Honjo K, Xu X, Bucy RP. CD4+ T-cell receptor transgenic $\mathrm{T}$ cells alone can reject vascularized heart transplants through the indirect pathway of alloantigen recognition. Transplantation (2004) 77:452-5. doi: 10.1097/01.TP.0000112937.12491.42

43. Honjo K, Yan Xu X, Kapp JA, Bucy RP. Evidence for cooperativity in the rejection of cardiac grafts mediated by CD4 TCR Tg $\mathrm{T}$ cells specific for a defined allopeptide. Am J Transplant. (2004) 4:1762-8. doi: 10.1046/j.1600-6143.2004.00596.x

44. Liu Z, Colovai AI, Tugulea S, Reed EF, Fisher PE, Mancini D, et al. Indirect recognition of donor HLA-DR peptides in organ allograft rejection. J Clin Invest. (1996) 98:1150-7. doi: 10.1172/JCI118898

45. Vella JP, Spadafora-Ferreira M, Murphy B, Alexander SI, Harmon W, Carpenter $\mathrm{CB}$, et al. Indirect allorecognition of major histocompatibility complex allopeptides in human renal transplant recipients with chronic graft dysfunction. Transplantation (1997) 64:795-800. doi: 10.1097/00007890-199709270-00001

46. Reznik SI, Jaramillo A, SivaSai KS, Womer KL, Sayegh MH, Trulock EP, et al. Indirect allorecognition of mismatched donor HLA class II peptides in lung transplant recipients with bronchiolitis obliterans syndrome. Am J Transplant. (2001) 1:228-35. doi: 10.1034/j.1600-6143.2001.00100 3228.x

47. Rosenberg AS, Singer A. Cellular basis of skin allograft rejection: an in vivo model of immune- mediated tissue destruction. Annu Rev Immunol. (1992) 10:333-58. doi: 10.1146/annurev.iy.10.040192.002001

48. Ridge JP, Di Rosa F, Matzinger P. A conditioned dendritic cell can be a temporal bridge between a CD4 $+\mathrm{T}$ - helper and a T-killer cell [see comments]. Nature (1998) 393:474-8. doi: 10.1038/30989

49. Bennett SR, Carbone FR, Karamalis F, Flavell RA, Miller JF, Heath WR. Help for cytotoxic-T-cell responses is mediated by CD40 signalling [see comments]. Nature (1998) 393:478-80. doi: 10.1038/30996

50. Schoenberger SP, Toes RE, van der Voort EI, Offringa R, Melief CJ. T-cell help for cytotoxic $\mathrm{T}$ lymphocytes is mediated by CD40-CD40L interactions [see comments]. Nature (1998) 393:480-3. doi: 10.1038/ 31002

51. Taylor AL, Negus SL, Negus M, Bolton EM, Bradley JA, Pettigrew GJ. Pathways of helper CD4 T cell allorecognition in generating alloantibody and CD8 T cell alloimmunity. Transplantation (2007) 83:931-7. doi: 10.1097/01.tp.0000257960.07783.e3

52. Lee RS, Grusby MJ, Glimcher LH, Winn HJ, Auchincloss H Jr. Indirect recognition by helper cells can induce donor-specific cytotoxic T lymphocytes in vivo. J Exp Med. (1994) 179:865-72.

53. Bestard O, Cruzado JM, Lucia M, Crespo E, Casis L, Sawitzki B, et al. Prospective assessment of antidonor cellular alloreactivity is a tool for guidance of immunosuppression in kidney transplantation. Kidney Int. (2013) 84:1226-36. doi: 10.1038/ki.2013.236

54. Poggio ED, Clemente M, Riley J, Roddy M, Greenspan NS, Dejelo $\mathrm{C}$, et al. Alloreactivity in renal transplant recipients with and without chronic allograft nephropathy. J Am Soc Nephrol. (2004) 15:1952-60. doi: 10.1097/01.ASN.0000129980.83334.79

55. Crespo E, Cravedi P, Martorell J, Luque S, Melilli E, Cruzado JM, et al. Posttransplant peripheral blood donor-specific interferon-gamma enzymelinked immune spot assay differentiates risk of subclinical rejection and de novo donor-specific alloantibodies in kidney transplant recipients. Kidney Int. (2017) 92:201-13. doi: 10.1016/j.kint.2016.12.024

56. Bestard O, Nickel P, Cruzado JM, Schoenemann C, Boenisch O, Sefrin $\mathrm{A}$, et al. Circulating alloreactive $\mathrm{T}$ cells correlate with graft function in longstanding renal transplant recipients. J Am Soc Nephrol. (2008) 19:1419-29. doi: 10.1681/ASN.2007050539

57. Yap M, Boeffard F, Clave E, Pallier A, Danger R, Giral M, et al. Expansion of highly differentiated cytotoxic terminally differentiated effector memory CD8 $+\mathrm{T}$ cells in a subset of clinically stable kidney transplant recipients: a potential marker for late graft dysfunction. J Am Soc Nephrol. (2014) 25:1856-68. doi: 10.1681/ASN.2013080848

58. Obst R, van Santen HM, Mathis D, Benoist C. Antigen persistence is required throughout the expansion phase of a CD4(+) T cell response. J Exp Med. (2005) 201:1555-65. doi: 10.1084/jem.20042521

59. Grazia TJ, Pietra BA, Johnson ZA, Kelly BP, Plenter RJ, Gill RG. A two-step model of acute CD4 T-cell mediated cardiac allograft rejection. J Immunol. (2004) 172:7451-8. doi: 10.4049/jimmunol.172.12.7451

60. Pietra BA, Wiseman A, Bolwerk A, Rizeq M, Gill RG. CD4 T cell-mediated cardiac allograft rejection requires donor but not host MHC class II. J Clin Invest. (2000) 106:1003-10. doi: 10.1172/JCI10467

61. Valujskikh A, Hartig C, Heeger PS. Indirectly primed CD8+ T cells are a prominent component of the allogeneic $\mathrm{T}$-cell repertoire after skin graft rejection in mice. Transplantation (2001) 71:418-21. doi: 10.1097/00007890-200102150-00014

62. Valujskikh A, Lantz O, Celli S, Matzinger P, Heeger PS. Cross-primed CD8(+) T cells mediate graft rejection via a distinct effector pathway. Nat Immunol. (2002) 3:844-51. doi: 10.1038/ni831

63. Valujskikh A, Zhang Q, Heeger PS. CD8 T cells specific for a donorderived, self-restricted transplant antigen are nonpathogenic bystanders after vascularized heart transplantation in mice. J Immunol. (2006) 176:2190-6. doi: 10.4049/jimmunol.176.4.2190

64. Pettigrew GJ, Lovegrove E, Bradley JA, Maclean J, Bolton EM. Indirect $\mathrm{T}$ cell allorecognition and alloantibody-mediated rejection of MHC class I-disparate heart grafts. J Immunol. (1998) 161:1292-8.

65. Fangmann J, Dalchau R, Fabre JW. Rejection of skin allografts by indirect allorecognition of donor class I major histocompatibility complex peptides. $J$ Exp Med. (1992) 175:1521-9. doi: 10.1084/jem.175.6.1521

66. Honjo K, Xu XY, Bucy RP. Heterogeneity of $\mathrm{T}$ cell clones specific for a single indirect alloantigenic epitope (I-Ab/H-2Kd54-68) that mediate transplant rejection. Transplantation (2000) 70:1516-24. doi: 10.1097/00007890-200011270-00020

67. Valujskikh A, Matesic D, Gilliam A, Anthony D, Haqqi TM, Heeger PS. $\mathrm{T}$ cells reactive to a single immunodominant self-restricted allopeptide induce skin graft rejection in mice. J Clin Invest. (1998) 101:1398-407. doi: 10.1172/JCI893

68. Steele DJ, Laufer TM, Smiley ST, Ando Y, Grusby MJ, Glimcher LH, et al. Two levels of help for B cell alloantibody production. J Exp Med. (1996) 183:699-703. doi: 10.1084/jem.183.2.699 
69. Conlon TM, Saeb-Parsy K, Cole JL, Motallebzadeh R, Qureshi MS, Rehakova $\mathrm{S}$, et al. Germinal center alloantibody responses are mediated exclusively by indirect-pathway CD4 T follicular helper cells. J Immunol. (2012) 188:2643-52. doi: 10.4049/jimmunol.1102830

70. Tilly G, Doan-Ngoc TM, Yap M, Caristan A, Jacquemont L, Danger $\mathrm{R}$, et al. IL-15 Harnesses pro-inflammatory function of TEMRA CD8 in kidney-transplant recipients. Front Immunol. (2017) 8:778. doi: 10.3389/fimmu.2017.00778

71. McKinney EF, Smith KG. T cell exhaustion and immune-mediated diseasethe potential for therapeutic exhaustion. Curr Opin Immunol. (2016) 43:74-80. doi: 10.1016/j.coi.2016.09.005

72. Wherry EJ, Kurachi M. Molecular and cellular insights into T cell exhaustion. Nat Rev Immunol. (2015) 15:486-99. doi: 10.1038/nri3862

73. Aubert RD, Kamphorst AO, Sarkar S, Vezys V, Ha SJ, Barber DL, et al. Antigen-specific CD4 T-cell help rescues exhausted CD8 T cells during chronic viral infection. Proc Natl Acad Sci USA. (2011) 108:21182-7. doi: 10.1073/pnas.1118450109

74. Harper IG, Ali JM, Harper SJ, Wlodek E, Alsughayyir J, Negus MC, et al. Augmentation of recipient adaptive alloimmunity by donor passenger lymphocytes within the transplant. Cell Rep. (2016) 15:1214-27. doi: 10.1016/j.celrep.2016.04.009

75. Brink R. The imperfect control of self-reactive germinal center B cells. Curr Opin Immunol. (2014) 28:97-101. doi: 10.1016/j.coi.2014.03.001

76. Domeier PP, Schell SL, Rahman ZS. Spontaneous germinal centers and autoimmunity. Autoimmunity (2017) 50:4-18. doi: 10.1080/08916934.2017.1280671

77. Vinuesa CG, Linterman MA, Yu D, MacLennan IC. Follicular Helper T cells. Annu Rev Immunol. (2016). 34:335-68. doi: 10.1146/annurev-immunol-041015-055605

78. McKinney EF, Lee JC, Jayne DR, Lyons PA, Smith KG. T-cell exhaustion, co-stimulation and clinical outcome in autoimmunity and infection. Nature (2015) 523:612-6. doi: 10.1038/nature14468

79. Sanchez-Fueyo A, Markmann JF. Immune exhaustion and transplantation. Am J Transplant. (2016) 16:1953-7. doi: 10.1111/ajt.13702

80. Kahan SM, Wherry EJ, Zajac AJ. T cell exhaustion during persistent viral infections. Virology (2015) 479-480:180-93. doi: 10.1016/j.virol.2014. 12.033

81. Fahey LM, Wilson EB, Elsaesser H, Fistonich CD, McGavern DB, Brooks DG. Viral persistence redirects CD4 T cell differentiation toward T follicular helper cells. J Exp Med. (2011) 208:987-99. doi: 10.1084/jem.201 01773

82. Zotos D, Coquet JM, Zhang Y, Light A, D'Costa K, Kallies A, et al. IL-21 regulates germinal center $B$ cell differentiation and proliferation through a B cell-intrinsic mechanism. J Exp Med. (2010) 207:365-78. doi: 10.1084/jem.20091777

83. Elsaesser H, Sauer K, Brooks DG. IL-21 is required to control chronic viral infection. Science (2009) 324:1569-72. doi: 10.1126/science.1174182

84. Frohlich A, Kisielow J, Schmitz I, Freigang S, Shamshiev AT, Weber J, et al. IL-21R on T cells is critical for sustained functionality and control of chronic viral infection. Science (2009) 324:1576-80. doi: 10.1126/science. 1172815

85. Yi JS, Du M, Zajac AJ. A vital role for interleukin-21 in the control of a chronic viral infection. Science. (2009) 324:1572-6. doi: 10.1126/science.1175194.

86. Vella LA, Herati RS, Wherry EJ. CD4(+) T cell differentiation in chronic viral infections: the Tfh perspective. Trends Mol Med. (2017) 23:1072-87. doi: 10.1016/j.molmed.2017.10.001

87. Sarraj B, Ye J, Akl AI, Chen G, Wang JJ, Zhang Z, et al. Impaired selectindependent leukocyte recruitment induces T-cell exhaustion and prevents chronic allograft vasculopathy and rejection. Proc Natl Acad Sci USA. (2014) 111:12145-50. doi: 10.1073/pnas.1303676111

88. Benichou G, Malloy KM, Tam RC, Heeger PS, Fedoseyeva EV. The presentation of self and allogeneic MHC peptides to T lymphocytes. Hum Immunol. (1998) 59:540-8. doi: 10.1016/S0198-8859(98)00059-7

89. Fedoseyeva EV, Zhang F, Orr PL, Levin D, Buncke HJ, Benichou G. De novo autoimmunity to cardiac myosin after heart transplantation and its contribution to the rejection process. J Immunol. (1999) 162:6836-42.
90. Subramanian V, Ramachandran S, Banan B, Bharat A, Wang X, Benshoff $\mathrm{N}$, et al. Immune response to tissue-restricted self-antigens induces airway inflammation and fibrosis following murine lung transplantation. Am J Transplant. (2014) 14:2359-66. doi: 10.1111/ajt. 12908

91. Conlon TM, Cole JL, Motallebzadeh R, Harper I, Callaghan CJ, Bolton EM, et al. Unlinked memory helper responses promote long-lasting humoral alloimmunity. J Immunol. (2012) 189:5703-12. doi: 10.4049/jimmunol.1202257

92. Benichou G, Gonzalez B, Marino J, Ayasoufi K, Valujskikh A. Role of memory T cells in allograft rejection and tolerance. Front Immunol. (2017) 8:170. doi: 10.3389/fimmu.2017.00170

93. Adams AB, Pearson TC, Larsen CP. Heterologous immunity: an overlooked barrier to tolerance. Immunol Rev. (2003) 196:147-60. doi: 10.1046/j.1600-065X.2003.00082.x

94. Adams AB, Williams MA, Jones TR, Shirasugi N, Durham MM, Kaech SM, et al. Heterologous immunity provides a potent barrier to transplantation tolerance. J Clin Invest. (2003) 111:1887-95. doi: 10.1172/JCI2003 17477

95. Campos EF, Tedesco-Silva H, Machado PG, Franco M, Medina-Pestana JO, Gerbase-DeLima M. Post-transplant anti-HLA class II antibodies as risk factor for late kidney allograft failure. Am J Transplant. (2006) 6:2316-20. doi: 10.1111/j.1600-6143.2006.01503.x

96. DeVos JM, Gaber AO, Knight RJ, Land GA, Suki WN, Gaber LW, et al. Donor-specific HLA-DQ antibodies may contribute to poor graft outcome after renal transplantation. Kidney Int. (2012) 82:598-604. doi: 10.1038/ki.2012.190

97. Wood KJ, Bushell A, Hester J. Regulatory immune cells in transplantation. Nat Rev Immunol. (2012) 12:417-30. doi: 10.1038/nri3227

98. Sakaguchi S, Sakaguchi N, Asano M, Itoh M, Toda M. Immunologic selftolerance maintained by activated $\mathrm{T}$ cells expressing IL-2 receptor alphachains (CD25). Breakdown of a single mechanism of self-tolerance causes various autoimmune diseases. J Immunol. (1995) 155:1151-64.

99. Tang Q, Vincenti F. Transplant trials with tregs: perils and promises. J Clin Invest. (2017) 127:2505-12. doi: 10.1172/JCI90598

100. Fontenot JD, Gavin MA, Rudensky AY. Foxp3 programs the development and function of CD4+CD25+ regulatory T cells. Nat Immunol. (2003) 4:330-6. doi: 10.1038/ni904

101. Khattri R, Cox T, Yasayko SA, Ramsdell F. An essential role for Scurfin in CD4+CD25+ T regulatory cells. Nat Immunol. (2003) 4:337-42. doi: $10.1038 /$ ni909

102. Cao X, Cai SF, Fehniger TA, Song J, Collins LI, Piwnica-Worms DR, et al. Granzyme B and perforin are important for regulatory $\mathrm{T}$ cellmediated suppression of tumor clearance. Immunity (2007) 27:635-46. doi: 10.1016/j.immuni.2007.08.014

103. Bilate $\mathrm{AM}$, Lafaille JJ. Induced CD4+Foxp3+ regulatory $\mathrm{T}$ cells in immune tolerance. Annu Rev Immunol. (2012) 30:733-58. doi: 10.1146/annurev-immunol-020711-075043

104. Kanamori M, Nakatsukasa H, Okada M, Lu Q, Yoshimura A. Induced regulatory $\mathrm{T}$ cells: their development, stability, and applications. Trends Immunol. (2016) 37:803-11. doi: 10.1016/j.it.2016.08.012

105. Sagoo P, Ali N, Garg G, Nestle FO, Lechler RI, Lombardi G. Human regulatory $\mathrm{T}$ cells with alloantigen specificity are more potent inhibitors of alloimmune skin graft damage than polyclonal regulatory T cells. Sci Transl Med. (2011) 3:83ra42. doi: 10.1126/scitranslmed.3002076

106. Tsang JY, Tanriver Y, Jiang S, Xue SA, Ratnasothy K, Chen D, et al. Conferring indirect allospecificity on CD4+CD25+ Tregs by TCR gene transfer favors transplantation tolerance in mice. J Clin Invest. (2008) 118:3619-28. doi: 10.1172/JCI33185

107. Joffre O, Santolaria T, Calise D, Al Saati T, Hudrisier D, Romagnoli $\mathrm{P}$, et al. Prevention of acute and chronic allograft rejection with CD4+CD25+Foxp3+ regulatory T lymphocytes. Nat Med. (2008) 14:88-92. doi: $10.1038 / \mathrm{nm} 1688$

108. Newell KA, Phippard D, Turka LA. Regulatory cells and cell signatures in clinical transplantation tolerance. Curr Opin Immunol. (2011) 23:655-9. doi: 10.1016/j.coi.2011.07.008

109. Trzonkowski P, Bieniaszewska M, Juscinska J, Dobyszuk A, Krzystyniak A, Marek N, et al. First-in-man clinical results of the treatment of 
patients with graft versus host disease with human ex vivo expanded CD4+CD25+CD127- T regulatory cells. Clinical Immunol. (2009) 133:22-6. doi: 10.1016/j.clim.2009.06.001

110. Brunstein CG, Miller JS, Cao Q, McKenna DH, Hippen KL, Curtsinger J, et al. Infusion of ex vivo expanded T regulatory cells in adults transplanted with umbilical cord blood: safety profile and detection kinetics. Blood (2011) 117:1061-70. doi: 10.1182/blood-2010-07-293795

111. Di Ianni M, Falzetti F, Carotti A, Terenzi A, Castellino F, Bonifacio E, et al. Tregs prevent GVHD and promote immune reconstitution in HLA-haploidentical transplantation. Blood (2011) 117:3921-8. doi: 10.1182/blood-2010-10-311894

112. Romano M, Tung SL, Smyth LA, Lombardi G. Treg therapy in transplantation: a general overview. Transpl Int. (2017) 30:745-53. doi: 10.1111/tri.12909

113. Kim JI, Lee MKt, Moore DJ, Sonawane SB, Duff PE, O’Connor MR, et al. Regulatory T-cell counter-regulation by innate immunity is a barrier to transplantation tolerance. Am J Transplant. (2009) 9:2736-44. doi: 10.1111/j.1600-6143.2009.02847.x

114. Lee K, Nguyen V, Lee KM, Kang SM, Tang Q. Attenuation of donorreactive $\mathrm{T}$ cells allows effective control of allograft rejection using regulatory T cell therapy. Am J Transplant. (2014) 14:27-38. doi: 10.1111/ajt. 12509

115. Yamada A, Chandraker A, Laufer TM, Gerth AJ, Sayegh MH, Auchincloss $\mathrm{H}$ Jr. Recipient MHC class II expression is required to achieve longterm survival of murine cardiac allografts after costimulatory blockade. $J$ Immunol. (2001) 167:5522-6. doi: 10.4049/jimmunol.167.10.5522

116. Wise MP, Bemelman F, Cobbold SP, Waldmann H. Linked suppression of skin graft rejection can operate through indirect recognition. J Immunol. (1998) 161:5813-6.

117. Graca L, Le Moine A, Cobbold SP, Waldmann H. Dominant transplantation tolerance. Opinion. Curr Opin Immunol. (2003) 15:499-506. doi: 10.1016/S0952-7915(03)00098-0

118. Qin S, Cobbold SP, Pope H, Elliott J, Kioussis D, Davies J, et al. "Infectious" transplantation tolerance. Science (1993) 259:974-7. doi: 10.1126/science.8094901

119. Waldmann H, Adams E, Fairchild P, Cobbold S. Infectious tolerance and the long-term acceptance of transplanted tissue. Immunol Rev. (2006) 212:301-13. doi: 10.1111/j.0105-2896.2006.00406.x

120. Buck MD, O’Sullivan D, Pearce EL. T cell metabolism drives immunity. J Exp Med. (2015) 212:1345-60. doi: 10.1084/jem.20151159

121. Man K, Kallies A. Synchronizing transcriptional control of T cell metabolism and function. Nat Rev Immunol. (2015) 15:574-84. doi: 10.1038/nri 3874

122. Delgoffe GM, Powell JD. Feeding an army: the metabolism of T cells in activation, anergy, and exhaustion. Mol Immunol. (2015) 68(2 Pt C):492-6. doi: 10.1016/j.molimm.2015.07.026

123. Sena LA, Li S, Jairaman A, Prakriya M, Ezponda T, Hildeman DA, et al. Mitochondria are required for antigen-specific $\mathrm{T}$ cell activation through reactive oxygen species signaling. Immunity (2013) 38:225-36. doi: 10.1016/j.immuni.2012.10.020

124. Saxton RA, Sabatini DM. mTOR Signaling in growth, metabolism, and disease. Cell. (2017) 168:960-76. doi: 10.1016/j.cell.2017.02.004

125. Han JM, Patterson SJ, Levings MK. The Role of the PI3K signaling pathway in CD4(+) T cell differentiation and function. Front Immunol. (2012) 3:245. doi: 10.3389/fimmu.2012.00245

126. Ramanathan A, Schreiber SL. Direct control of mitochondrial function by mTOR. Proc Natl Acad Sci USA. (2009) 106:22229-32. doi: 10.1073/pnas.0912074106

127. Zhao S, Torres A, Henry RA, Trefely S, Wallace M, Lee JV, et al. ATP-Citrate lyase controls a glucose-to-acetate metabolic switch. Cell Rep. (2016) 17:1037-52. doi: 10.1016/j.celrep.2016. 09.069

128. Blagih J, Coulombe F, Vincent EE, Dupuy F, Galicia-Vazquez G, Yurchenko E, et al. The energy sensor AMPK regulates $\mathrm{T}$ cell metabolic adaptation and effector responses in vivo. Immunity (2015) 42:41-54. doi: 10.1016/j.immuni.2014.12.030

129. O’Sullivan D, van der Windt GJ, Huang SC, Curtis JD, Chang CH, Buck $\mathrm{MD}$, et al. Memory CD8(+) T cells use cell-intrinsic lipolysis to support the metabolic programming necessary for development. Immunity (2014) 41:75-88. doi: 10.1016/j.immuni.2014.06.005

130. Pearce EL, Walsh MC, Cejas PJ, Harms GM, Shen H, Wang LS, et al. Enhancing CD8 T-cell memory by modulating fatty acid metabolism. Nature (2009) 460:103-7. doi: 10.1038/nature08097

131. van der Windt GJ, Everts B, Chang CH, Curtis JD, Freitas TC, Amiel E, et al. Mitochondrial respiratory capacity is a critical regulator of CD8+ T cell memory development. Immunity (2012) 36:68-78. doi: 10.1016/j.immuni.2011.12.007

132. Michalek RD, Gerriets VA, Jacobs SR, Macintyre AN, MacIver NJ, Mason EF, et al. Cutting edge: distinct glycolytic and lipid oxidative metabolic programs are essential for effector and regulatory CD4+ $\mathrm{T}$ cell subsets. J Immunol. (2011) 186:3299-303. doi: 10.4049/jimmunol.1003613

133. Huynh A, Zhang R, Turka LA. Signals and pathways controlling regulatory T cells. Immunol Rev. (2014) 258:117-31. doi: 10.1111/imr.12148

134. Delgoffe GM, Kole TP, Zheng Y, Zarek PE, Matthews KL, Xiao $B$, et al. The mTOR kinase differentially regulates effector and regulatory $\mathrm{T}$ cell lineage commitment. Immunity (2009) 30:832-44. doi: 10.1016/j.immuni.2009.04.014

135. Dang EV, Barbi J, Yang HY, Jinasena D, Yu H, Zheng Y, et al. Control of $\mathrm{T}(\mathrm{H}) 17 / \mathrm{T}$ (reg) balance by hypoxia-inducible factor 1. Cell (2011) 146:77284. doi: 10.1016/j.cell.2011.07.033

136. Shi LZ, Wang R, Huang G, Vogel P, Neale G, Green DR, et al. HIFlalphadependent glycolytic pathway orchestrates a metabolic checkpoint for the differentiation of TH17 and Treg cells. J Exp Med. (2011) 208:1367-76. doi: 10.1084/jem.20110278

137. Ray JP, Staron MM, Shyer JA, Ho PC, Marshall HD, Gray SM, et al. The Interleukin-2-mTORc1 kinase axis defines the signaling, differentiation, and metabolism of T Helper 1 and Follicular B Helper T cells. Immunity (2015) 43:690-702. doi: 10.1016/j.immuni.2015.08.017

138. Oestreich KJ, Read KA, Gilbertson SE, Hough KP, McDonald PW, Krishnamoorthy $\mathrm{V}$, et al. Bcl-6 directly represses the gene program of the glycolysis pathway. Nat Immunol. (2014) 15:957-64. doi: 10.1038/ ni. 2985

139. Bengsch B, Johnson AL, Kurachi M, Odorizzi PM, Pauken KE, Attanasio J, et al. Bioenergetic insufficiencies due to metabolic alterations regulated by the inhibitory receptor PD-1 Are an early driver of $\mathrm{CD} 8(+) \mathrm{T}$ cell exhaustion. Immunity (2016) 45:358-73. doi: 10.1016/j.immuni.2016.07.008

140. Oestreich KJ, Yoon H, Ahmed R, Boss JM. NFATcl regulates PD1 expression upon $\mathrm{T}$ cell activation. J Immunol. (2008) 181:4832-9. doi: 10.4049/jimmunol.181.7.4832

141. Martinez GJ, Pereira RM, Aijo T, Kim EY, Marangoni F, Pipkin ME, et al. The transcription factor NFAT promotes exhaustion of activated CD8 $(+)$ T cells. Immunity (2015) 42:265-78. doi: 10.1016/j.immuni.2015.01.006

142. Patsoukis N, Bardhan K, Chatterjee P, Sari D, Liu B, Bell LN, et al. PD-1 alters T-cell metabolic reprogramming by inhibiting glycolysis and promoting lipolysis and fatty acid oxidation. Nat Commun. (2015) 6:6692. doi: $10.1038 /$ ncomms7692

143. Yin Y, Choi SC, Xu Z, Perry DJ, Seay H, Croker BP, et al. Normalization of CD4+ T cell metabolism reverses lupus. Sci Transl Med. (2015) 7:274ra18. doi: 10.1126/scitranslmed.aaa0835

144. Lee CF, Lo YC, Cheng CH, Furtmuller GJ, Oh B, Andrade-Oliveira V, et al. Preventing allograft rejection by targeting immune metabolism. Cell Rep. (2015) 13:760-70. doi: 10.1016/j.celrep.2015.09.036

145. Byersdorfer CA, Tkachev V, Opipari AW, Goodell S, Swanson J, Sandquist $S$, et al. Effector $\mathrm{T}$ cells require fatty acid metabolism during murine graft-versus-host disease. Blood (2013) 122:3230-7. doi: 10.1182/blood-2013-04-495515

146. Battaglia M, Stabilini A, Roncarolo MG. Rapamycin selectively expands CD4+CD25+FoxP3+ regulatory $\mathrm{T}$ cells. Blood (2005) 105:4743-8. doi: 10.1182/blood-2004-10-3932

147. Araki K, Turner AP, Shaffer VO, Gangappa S, Keller SA, Bachmann MF, et al. mTOR regulates memory CD8 T-cell differentiation. Nature (2009) 460:108-12. doi: 10.1038/nature08155

148. Sukumar M, Liu J, Ji Y, Subramanian M, Crompton JG, Yu Z, et al. Inhibiting glycolytic metabolism enhances CD8+ $\mathrm{T}$ cell memory and 
antitumor function. J Clin Invest. (2013) 123:4479-88. doi: 10.1172/JCI 69589

149. Huynh A, DuPage M, Priyadharshini B, Sage PT, Quiros J, Borges CM, et al. Control of PI(3) kinase in Treg cells maintains homeostasis and lineage stability. Nat Immunol. (2015) 16:188-96. doi: 10.1038/ni.3077

150. Shrestha S, Yang K, Guy C, Vogel P, Neale G, Chi H. Treg cells require the phosphatase PTEN to restrain TH1 and TFH cell responses. Nat Immunol. (2015) 16:178-87. doi: 10.1038/ni.3076

151. Vincenti F, Rostaing L, Grinyo J, Rice K, Steinberg S, Gaite L, et al. Belatacept and long-term outcomes in kidney transplantation. N Engl J Med. (2016) 374:333-43. doi: 10.1056/NEJMoa1506027
Conflict of Interest Statement: The authors declare that the research was conducted in the absence of any commercial or financial relationships that could be construed as a potential conflict of interest.

Copyright (c) 2018 Siu, Surendrakumar, Richards and Pettigrew. This is an openaccess article distributed under the terms of the Creative Commons Attribution License (CC BY). The use, distribution or reproduction in other forums is permitted, provided the original author(s) and the copyright owner(s) are credited and that the original publication in this journal is cited, in accordance with accepted academic practice. No use, distribution or reproduction is permitted which does not comply with these terms. 